Article

\title{
Construction Waste Management Profiles, Practices, and Performance: A Cross-Jurisdictional Analysis in Four Countries
}

\author{
Vivian Wing-Yan Tam ${ }^{1, *}$ and Weisheng $\mathrm{Lu}^{2,3}$ \\ 1 School of Computing, Engineering and Mathematics and Institute for Infrastructure Engineering, \\ Western Sydney University, Locked Bag 1797, Penrith NSW 2751, Australia \\ 2 Department of Real Estate and Construction, Faculty of Architecture, The University of Hong Kong, \\ Pokfulam, Hong Kong; wilsonlu@hku.hk \\ 3 Shenzhen Institute of Research and Innovation (SIRI), The University of Hong Kong, B402, \\ Shenzhen Virtual University Park, Nanshan District, Shenzhen 518057, China \\ * Correspondence: v.tam@westernsydney.edu.au or vivianwytam@gmail.com; Tel.: +61-2-4736-0105; \\ Fax: +61-2-4736-0833
}

Academic Editors: Giuseppe Ioppolo and Marc A. Rosen

Received: 11 November 2015; Accepted: 18 February 2016; Published: 22 February 2016

\begin{abstract}
Construction waste management (CWM) has received worldwide attention for some time. As a result, a plethora of research, investigating a wide array of CWM issues such as their profiles, practices, and performance, has been reported in individual economies around the globe. However, a cross-jurisdictional comparison of these issues is limitedly presented in the literature despite its importance to benchmarking performance and identifying best CWM practices in the context of globalization whereby knowledge sharing has already transcended traditional country boundaries. The aim of this ex post facto research is to compare CWM profiles, practices, and performance in Australia, Europe (Europe refers to EU-27 member countries in the European Union, including Belgium, France, Germany, Italy, Luxembourg, Netherlands, Denmark, Great Britain, Ireland, Portugal, Spain, Greece, Austria, Finland, Sweden, Czech Republic, Estonia, Hungary, Latvia, Lithuania, Poland, Slovakia, Slovenia, Malta, Cyprus, Bulgaria, and Romania.), Hong Kong, and the United Kingdom at a national-level, with a view to facilitating CWM knowledge sharing internationally. It does so by triangulating empirical data collected from various national statistical yearbooks with research papers and professional reports on CWM in these economies. It is found that in producing one million (US) dollars' work, construction contributes a volume of solid waste ranging from 28 to 121 tons among countries. Conscientious CWM practices can make a significant difference in reducing, reusing, or recycling construction waste, as evident in the large variation in the CWM performance. While it might be oversimplified to conclude that the best practices in one country can be applied in another, the research provides insightful references into sharing CWM knowledge across boundaries.
\end{abstract}

Keywords: construction waste; waste management; cross-jurisdictional analysis; Australia; Europe; Hong Kong; the United Kingdom

\section{Introduction}

During the past decades, construction and demolition (C \& D) waste has received increasing attention from both practitioners and researchers around the world [1-10]. C \& D activities can generate a wide range of different waste materials, which are not just rubbish and unwanted materials, but also includes excavated materials such as rock and soil, waste asphalt, bricks, concrete, plasterboard, timber and vegetation, asbestos, and contaminated soil [11]. C \& D waste often constitutes a prodigious 
portion of the total municipal solid waste (MSW) in contributing to environmental degradation [12-15]. For example, the statistics from Hong Kong Environmental Protection Department [16] showed that all waste received at landfills reached 13,844 tons per day (tpd) in 2012, or 5.05 million tons a year, of which about $25 \%$ is C \& D waste. It is reported in Mainland China C \& D activities produced more than two billion tons of C \& D waste in 2011 [17], and it is generally estimated that C \& D waste takes up around $30 \%-40 \%$ of total MSW in China [18]. Hyder Consulting [19] reported that a total of 19.0 million tons of C \& D waste was generated in Australia in 2008-2009; of this total waste stream, 8.5 million tons was disposed to landfill while 10.5 million tons, or $55 \%$, was recovered and recycled. Eurostat [20] estimated that a total of 857.2 million tons of C \& D waste was generated in the EU-27 Member States in 2010. Construction took up about $15 \%$ of all waste landfilled, while MSW was about 37\% [20]. Department for Environment Food \& Rural Affairs [21] in the United Kingdom reported that total construction waste generated in 2010 in England was 77.38 million tons. In the United States, the United States Environmental Protection Agency [22] estimated that approximately 170 million tons of building-related C \& D materials were generated during 2003.

Owing to its significant impact to the natural environment, C \& D waste needs to be properly managed. Considerable research efforts have been paid to the investigation of construction waste management (CWM) in individual economies. For example, Lu and Yuan [10] retrieved $147 \mathrm{CWM}$ research papers published on internationally renowned scholarly journals from 1996 to 2010, without counting the vast number of related research reports. These papers covered 35 countries and regions, amongst which the majority are developed economies and the top six most researched are Hong Kong, the United States, Australia, the United Kingdom, Malaysia, and China. These research papers investigated a wide array of CWM issues including C \& D waste definitions, measurement, waste management strategies such as reduce, reuse, and recycle, life-cycle thinking, polluter pays principle, and waste disposal charging scheme.

While the understanding of construction waste in individual economies has been significantly improved over the past decades, a cross-jurisdictional comparison of these issues is absent from the literature. This is abnormal given that nowadays knowledge sharing has commonly transcended traditional country boundaries with the development of globalization and new information and communication technologies. Today's C \& D waste together with its environmental impact in a particular region is no longer merely a local issue. Rather, it is important to benchmark performance and identify the best practices in different economies so that knowledge developed elsewhere can be shared in the international waste management community. This echoes with McCabe [23] who advocated that benchmarking key performance indicators and identifying the best practices is one of the key management techniques the construction industry needs to adopt if it is to meet the challenge of new efficiency and productivity targets. The efforts to promote a "greener" construction industry around the developed world have largely paid off [24].

The aim of this research is to report a cross-jurisdictional analysis of CWM in different economies with a view to facilitating CWM knowledge sharing in a global context. The research starts with developing an analytic framework that will guide the cross-jurisdictional analysis. By following the framework, CWM performance is calculated. The great advantage of cross-national comparisons is that, at their best, they force researchers to look at a total context and enable them to discover the greatest number of factors that are interactive and interdependent $[25,26]$. The paper addresses discrepancies among CWM practices in different economies and draws on data of construction volumes, project types, and construction technologies to link them with waste management performance.

\section{The Analytic Framework}

\subsection{Construction Waste Management Performance Indicators}

C \& D waste is defined as the waste that arises from construction, renovation, and demolition activities [27]. It may also include surplus and damaged products and materials arising in the course 
of construction work or used temporarily during the process of on-site activities [28]. Sometimes, it is called construction waste, representing inclusively the surplus materials generated by site clearance, excavation, construction, refurbishment, renovation, demolition, and road works [10].

There is another stream of research viewing that $C \& D$ waste should include non-value-adding works in construction [29] such as over engineering, excessively thick floors, or wasteful activities [30] such as unreasonable construction process, or unnecessary idling time. This view can be traced back to Ohno who defined waste as "any human activity which absorbs resources but creates no value" [31], and it was also supported by the studies $[29,32,33]$ and many lean construction advocators [34]. This view enables researchers to consider both material losses and non-value-adding works but, in this paper, construction waste refers to solid and tangible waste. In some economies such as the United Kingdom and Hong Kong, C \& D waste is further classified into inert and non-inert parts. Inert waste is defined as refuse, reject, or residue material that does not undergo biological, chemical, physical, or radiological transformation such as concrete waste while non-inert waste defines waste which decomposes or rots when deposited in landfills (including most household wastes) [35]. Non-inert waste is thus also called organic waste while the inert part is called inorganic waste.

In comparison with other pollutants such as dust and noise, C \& D waste is easy to see, as well as relatively easy to measure [33]. The cliché "you cannot improve what you cannot measure" offers a rationale for the research effort to identify proper CWM performance indicators. It is vital that CWM is closely monitored, and its performance is presented unambiguously for developing good CWM practices. To this end, a universal indicator that would facilitate benchmarking CWM performance across different economies is desired.

Waste generation rate (WGR) is one of the indicators that can serve the above purpose. The WGR can be calculated by dividing the waste in volume $\left(\mathrm{m}^{3}\right)$ or quantity (tons) by either the amount of virgin materials purchased, or the amount required by the design, or per $\mathrm{m}^{2}$ of gross floor area (GFA) [33]. A WGR can: (a) provide quantitative information for benchmarking different CWM practices at a project level; (b) help raise people's awareness of waste management in the construction industry, e.g., by timing the WGR with GFA, it is possible to calculate total quantity of C \& D waste and thus inform people of the negative impacts that construction activities have on the environment; and (c) assist contractors with developing effective CWM strategies by benchmarking it across different projects [10]. Indeed, there were studies investigating WGRs in different economies and comparing them with those in others, with a view to identifying the consequence of using different construction techniques, work procedures, and common practices $[5,8,10,33,36,37]$. However, the problem is that most of the empirical studies on WGR have a relatively small sample [10] or sampled relatively small sites due to the difficulties involved in conducting a survey on large-scale projects [38]. Results of such studies thus cannot justifiably be generalized to calculate the waste generation on other projects or at a macro level, i.e., herein to treat the construction industry in an economy as a whole.

The volume of $C \& D$ waste logged in various statistical resources is considered an ideal indicator for measuring and comparing CWM across different economies. Prolific studies have reported the amount of $C \& D$ waste generated in different economies. For example, in addition to the aforementioned reports on C \& D waste generation in the EU-27 member countries, United States, the United Kingdom, Hong Kong, and China, Tam [9] reported that C \& D waste forms $19 \%$ and $14 \%$ of the waste disposed of at landfills in Germany and Finland. These C \& D waste volumes, either in absolute terms or as a ratio of overall MSW, reflect the overall C \& D waste across different economies. However, the studies cannot reflect the efficiency of CWM practices. Moreover, the amount or ratio of C \& D waste is influenced by not only CWM practices but also a country's profile such as economy scale, population, territory, and waste management behaviors [10]; these practices should be considered in a cross-jurisdictional comparison.

It is thus proposed that ratio indicators such as C \& D waste per GDP should be added. Together with the C \& D waste volume indicators introduced above, they can help draw a big picture of CWM as 
well as reflect the efficiency of CWM practices in an economy. In summary, the performance indicators of CWM at a macro level can be listed as follows:

$I_{1}:$ Total C \& $D$ waste volume (million tons)

$I_{2}:$ Total inert $C \& D$ waste volume (million tons)

$I_{3}$ : Total non-inert $C \& D$ waste volume (million tons)

$I_{4}$ : Total volumes of $C \& D$ waste reduced, reused, and recycled (million tons)

$I_{5}$ : Total volume of $C \& D$ waste landfilled (million tons)

$I_{6}: C \& D$ waste generation per construction GDP (CDW/CGDP) (million tons/million US\$)

Particularly, the ratio $I_{6}: C \& D$ waste generation per construction GDP (CDW/CGDP) (million tons/million US\$) is introduced as an indicator that can be used to compare CWM practices across different jurisdictions. Here, CGDP is the gross domestic product contributed by a nation's construction sector measured in million US\$. It is a monetary measure of the value/worth of construction works. In producing every unit (e.g., million US\$) of construction worth, construction unavoidably will generate a certain amount of waste. Hence, the indicator can be used to gauge which nation's construction sector is less or more wasteful in terms of $C \& D$ waste generation. Actually, other ratio indicators such as $C \& D$ waste reduced/reused/recycles per construction $G D P\left(I_{4} / C G D P\right)$ or $C \& D$ waste landfilled per construction $G D P\left(I_{5} / C G D P\right)$ can be used for probing into CWM performance in different countries. However, the selection of these performance indicators is largely dependent on data availability. As can be seen later, not all countries' data is readily available for calculating the ratio indicators.

\subsection{Prevailing $C \& D$ Waste Management Practices}

There are two generic practices for dealing with C \& D waste. From a technical point of view, environmental engineers investigate how "hard" technologies can help manage C \& D waste, i.e., through introduction of prefabrication, using metal formwork, and using recycled aggregate for different concrete applications. By appreciating that C \& D waste is also a social issue, "soft" economical or managerial measures have gained momentum [39]. For example, based on the "polluter pays principle (PPP)", some governments have implemented a waste charging scheme as a major economic policy to impose a levy to the direct polluters who should be responsible for C \& $\mathrm{D}$ waste disposal. Similarly, there is an "extended producer responsibility (EPR)" suggesting that material vendors should be responsible for the waste generated from their supplies. In this paper, CWM practices refer to any technologies (e.g., cast in-situ, prefabrication, and recycling technologies), work procedures (e.g., on-site waste sorting), and other economical or managerial approaches (e.g., designing out waste, and waste disposal charging) that are relevant to CWM. It is assumed that different CWM practices would explain the variations of CWM performance amongst different economies.

CWM practices can also be categorized by the "3Rs" principle, which is known as the hierarchy of CWM. The principle refers to the $3 R$ s of reduce, reuse, and recycle, which classify waste management strategies according to their desirability [40]. The 3R principle is meant to be a hierarchy, arranged in ascending order of their adverse impacts to the environment from low to high. Reduction is considered as the most effective and efficient method for managing C \& D waste. It cannot only minimize the generation of $C \& D$ waste, but also reduce the cost for waste transporting, disposal, and recycling [41,42]. Researchers have proposed various solutions for waste reduction, which can be generally summarized into five categories [43,44], encompassing: (1) reducing waste through government legislation; (2) reducing waste by design; (3) developing an effective waste management system; (4) use of low waste technologies; and (5) improving practitioners' attitude toward waste reduction. Reuse means using the same material in construction more than once, including using the material again for the same function (e.g., formwork in construction) [45] and new-life reuse for a new function (e.g., using the cut-corner steel bar for shelves; using the stony fraction for road base material) [46]. It is the most desirable option after reduction because a minimum processing and energy use is achieved [40]. When reduction and reuse become too costly, recycling is desired. 
Tam [9] summarized that recycling can offer three benefits: (a) reducing the demand for new resources; (b) cutting down transport and production energy cost; and (c) utilizing waste which would otherwise be lost to landfill sites. The 3Rs could take place in a specific stage (e.g., inception, design, construction, maintenance, and demolition) or throughout the whole life-cycle of a construction project.

Notably, there are some major green evaluation systems such as the Building Research Establishment Environmental Assessment Method [47], Green Globes System [48], the Hong Kong Building Environmental Assessment Method [49], the Leadership in Energy and Environmental Design [50], the Green Star Environmental Rating System [51], the Green Mark Assessment [52], and the GB Tool [53]. Striving for earning the "green points" in these systems will directly encourage avoidance, reduction, reuse, or recycling of $C \& D$ waste. These green evaluation systems thus have impacts on CWM. To this end, this study considers the adoption of various green evaluation systems as an emerging CWM practice, but examines it as an overarching practice that could take place in any of the following four types:
$P_{1}$ : Avoid (e.g., waste minimization design, renovation instead of demolition)
$P_{2}$ : Reduce (e.g., using low waste construction technologies, deconstruction)
$P_{3}:$ Reuse (e.g., on-site sorting and reuse, cutting formwork for other uses)
$P_{4}$ : Recycle (e.g., setting up waste sorting plants, processing waste as aggregates)

\subsection{Economic Profiles in Relation to C \& D Waste Management}

The CWM practices would not explain all variations in CWM performance across different economies. The causal relationship between the CWM practices and their performance is also influenced by the economic background, in particular its construction profile. For example, the main C \& D waste in Hong Kong is concrete and wasted timber formwork while this may not be the same in the United Kingdom or the United States where cast in situ is not commonly adopted. Similarly, different development stages of an economy will have different implications to C \& D waste generation. For example, Bergsdal, Bohne [54] reported that in Norway demolition was the smallest C \& D activities, contributing only $8 \%$ in 1998 while construction and renovation contributed $52 \%$ and $40 \%$ respectively to waste generation. In China, owing to the urbanization, demolition is the major culprit for waste generation [17,55], while in Hong Kong relative balanced activities between demolition and new construction can be seen owing to the renewal of the decayed urban areas. Therefore, the economic and construction profiles will be identified as the control variables for this cross-jurisdictional analysis.

Intuitively, the bigger GDP of an economy, the more construction is needed to provide the infrastructure demanded by the economic activities. It is also comprehensible that the more construction projects, the more C \& D waste may be generated in general. As shown below, five major control variables that might be in relation to $C \& D$ waste management are identified. Particularly, the ratio variables $\left(C_{2}\right.$ and $\left.C_{4}\right)$ are introduced to eliminate the effects of population and construction workers on the variations of CWM performance:

$C_{1}:$ Total GDP (billion US\$)
$C_{2}:$ GDP per capita (US\$)
$C_{3}:$ Total construction output (million US\$)
$C_{4}:$ Construction productivity (million US\$)
$C_{5}:$ Construction of new buildings (numbers)
$C_{6}:$ Development stages of an economy $(0=U n d e r d e v e l o p e d, 1=$ developing, and $2=$ developed)

Based on the above analyses, an analytic framework for this cross-jurisdictional study is developed and illustrated in Figure 1. It assumes that different CWM practices have an effect on CWM performance. Meanwhile, economic and construction profiles should also be at play, though more in the backdrop, to impact CWM performance. By following this analytic framework, indicators for 
the profiles, practices, and performance can be identified and measured and their relationships can be statistically analyzed. It is iterated at this juncture that the aim of this research is to find the links between CWM performance indicators and CWM practices by putting them in different economic profiles with a view to deriving the best CWM practices that can be shared by international waste management community.

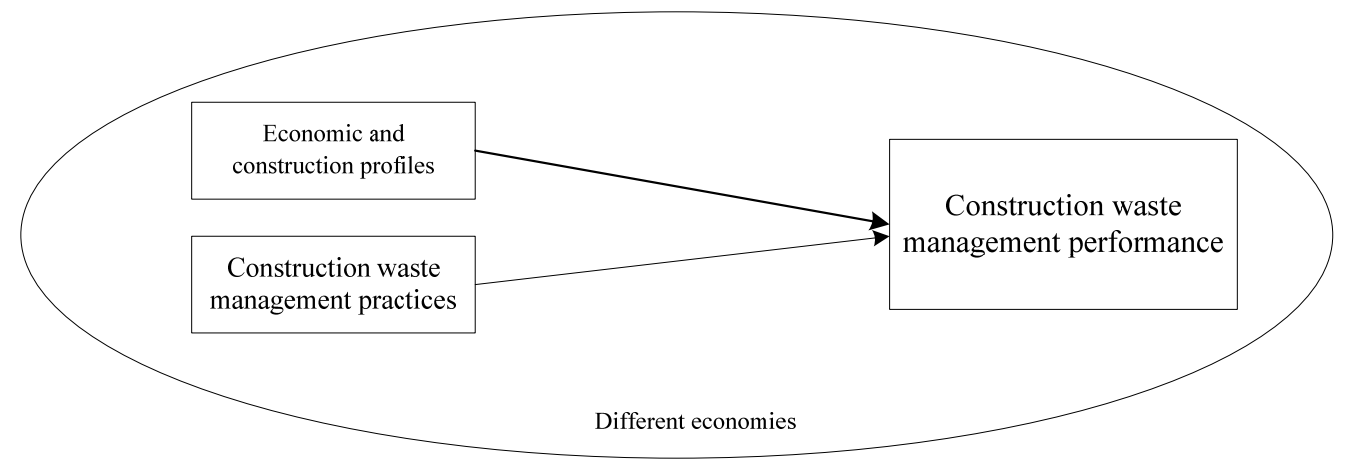

Figure 1. The analytic framework for comparing CWM profiles, practices, and performance across jurisdictions.

\section{Methodologies}

\subsection{Data Collection}

A mixed research methodology incorporating both quantitative and qualitative methods is adopted in this cross-jurisdictional study. Bearing in mind the analytic framework, the authors investigated two streams of resources to collect the data of performance, practices, and profiles as outlined in the previous sections in different economies. The selection of the economies to be compared is largely dependent on the data availability. Four economies including Australia, Europe, Hong Kong, and the United Kingdom are selected, while other major economies including the United States, China, and Japan are not included owing to their erratic data availability on C \& D waste generation.

The first stream of data sources is various national statistical yearbooks, which may provide data for the CWM performance indicators and economic profiles. From November 2012 to January 2013, the authors, with the assistances from two researchers, one from Spain and the other from Hong Kong, have managed to collect the data. The data resources are normally available online nowadays, and they are listed in Table 1. The authors decided to collect data over the past 10 years as a window for comparing CWM in different economies. Good efforts have been paid to understanding the statistical scopes and ensuring that they are comparable. As a result of this step, the data was collected and shown in Tables 2-5. The total C \& D waste volume $\left(I_{1}\right)$ per total GDP $\left(C_{1}\right) \times 1000$ is computed as the ratio $I_{6}: C \& D$ waste generation per construction GDP (CDW/CGDP) (tons/million US\$), which is introduced as an indicator for comparing CWM practices across different jurisdictions. The data shown in Appendices 1 to 4 is collected from available governmental reports and webpages. For easier verification, all data is actual data from the years without adjusting for inflation or exchanging to a certain currency. It is believed that if inflation, etc. is used for adjustment, it will be difficult to compare countries as different countries may have different inflation rates and fluctuating exchange rates.

The second stream of data sources is the research papers and reports from which the data of CWM practices in different economies will be collected. The 147 research papers retrieved by Lu and Yuan [10] based on a set of rigorous procedures are used as a point of departure for this task. The snowball sampling technique [56] is used to recruit more papers and reports falling in the area of $C \& D$ waste management in various economies. This led to 171 research papers and relevant reports. A content analysis was conducted to understand the literature and identify CWM practices in different economies. The method of content analysis, often included under the general rubric of 
"qualitative analysis", is a systematic, replicable technique for compressing many words of text into fewer content categories based on explicit rules of coding [57]. It enables researchers to include large amounts of textual information and systematically identify its properties. The coding process was conducted by the two authors independently, and the results were stored in two excels separately for further verifications. To reduce the potential bias underlying the content analyses, the agreement of the coded contents had to be made through many interactions, i.e., iteration or discussion between the two human coders. Given the nature of the textual information, this process was not guided by estimating inter-rater reliability, i.e., using Kappa coefficient, Index of Inconsistency, repeated measures ANOVA, and regression analysis. Instead, this was largely a subjective process but it benefited from prior knowledge that is possessed by the authors. Over the past decade, the authors have closely monitored CWM research to develop the domain knowledge in this field.

Table 1. A list of national statistical yearbooks as the data sources for this study.

\begin{tabular}{|c|c|c|}
\hline Economies & Data Sources & $\begin{array}{l}\text { Uniform Resource Locator } \\
\text { (URL) Addresses }\end{array}$ \\
\hline Australia & Australian Bureau of Statistics & $\begin{array}{l}\text { \{Australian Bureau of Statistics, } \\
2016 \# 3009 \text { \} }\end{array}$ \\
\hline European Union & Eurostat & $\{$ Eurostat, $2016 \# 3010\}$ \\
\hline China & National Bureau of Statistics of China & $\begin{array}{l}\text { \{National Bureau of Statistics of China, } \\
2016 \# 3011\}\end{array}$ \\
\hline Hong Kong & $\begin{array}{l}\text { Census and Statistics Department } \\
\text { (C \& SD), The Hong Kong SAR }\end{array}$ & $\begin{array}{l}\text { \{Census and Statistics Department, } \\
2016 \# 3012 \text { \} }\end{array}$ \\
\hline Japan & Statistics Bureau of Japan & \{Statistics Bureau of Japan, $2016 \# 3013$ \} \\
\hline The United Kingdom & $\begin{array}{l}\text { The United Kingdom } \\
\text { National Statistics }\end{array}$ & $\begin{array}{l}\text { \{The United Kingdom National } \\
\text { Statistics, } 2016 \# 3014\}\end{array}$ \\
\hline The United States of America & The United States government data & $\begin{array}{l}\text { \{The United States Government, } \\
2016 \# 3015\}\end{array}$ \\
\hline
\end{tabular}

It is noticed that for the economy and construction profiles, data is predominantly available as quantitative while the data for CWM practices is mainly qualitative in nature. To analyze their relationships with CWM performance is thus unavoidably characterized by the different quantitative and qualitative methods it involves.

\subsection{Pearson Correlation Analysis}

Correlation analysis measures the relationship between two items; it examines if changes in one item (independent variable) will result in changes in the other item (dependent variable). It is thus particularly suitable for this research, which aims to find out the relationships between CWM practices and performance and compare them across different economies. Pearson correlation analysis [58] is amongst the most commonly adopted correlation analysis methods. It shows the linear relationship between two sets of data: a positive correlation coefficient means an increase in the independent variable will lead to an increase in the variable depending on it. A negative correlation coefficient means the two variables are negatively correlated while a zero coefficient means the two variables are not statistically correlated. It is straightforward, and can be performed in most statistics analysis software programs, e.g., Statistical Package for the Social Sciences (SPSS), or R, which is an open source software for statistical computing and graphics. Nevertheless, it is a truism that correlation does not mean causality; this paper thus further explores the qualitative evidence from previous papers or reports to explain the statistical analyses.

\section{Data Analysis, Results, and Discussions}

\subsection{Correlations between CWM Performance and Its Economy and Construction Profile}

Mindful of the analytic framework, the correlations among the economic factors and CWM performance indicators are analyzed in order to fully understand their relationship. 
Tables 2-5 summarize the Pearson correlations between the said factors and indicators in four economies including Australia, Europe, Hong Kong, and the United Kingdom, respectively.

The sum of the reduced, reused, and recycled C \& D waste $\left(I_{4}\right)$ and landfill waste $\left(I_{5}\right)$ is the total C \& D waste $\left(I_{1}\right)$ for most countries if data is available. It is common to understand that the total C \& D waste $\left(I_{1}\right)$ has high correlations with the reduced, reused, and recycled C \& D waste $\left(I_{4}\right)$ and landfill waste $\left(I_{5}\right)$ among countries. These three indicators are largely consistent in terms of rise and fall over the past years of which correlations about 0.957 and -0.997 from $I_{4}$ and $I_{5}$ respectively with respect to $I_{1}$ are received for Europe and about 0.477 and 0.884 respectively are received for the United Kingdom. The relatively low correlation received with respect to $I_{4}$ and $I_{1}$ for the United Kingdom indicates that the reduced, reused, and recycled rates for $C \& D$ waste are slower than the $C \& D$ waste generation rate $\left(I_{1}\right)$. It should also be noted that the negative correlations for the landfill waste $\left(I_{5}\right)$ with respects to other CWM performance indicators for Europe show a reduction of landfill waste while the total C \& D waste $\left(I_{1}\right)$ and the total inert C \& D waste $\left(I_{2}\right)$ are increasing from the past years.

Table 2. Pearson correlations on the economic factors and CWM performance indicators for Australia.

\begin{tabular}{ccccccc}
\hline & $C_{1}$ & $C_{2}$ & $C_{3}$ & $C_{4}$ & $C_{5}$ & $I_{1}$ \\
\hline$C_{1}$ & 1.000 & 0.869 & 0.978 & 0.803 & -0.657 & 0.250 \\
$C_{2}$ & & 1.000 & 0.967 & 0.443 & -0.517 & 0.804 \\
$C_{3}$ & & & 1.000 & 0.679 & -0.624 & 0.843 \\
$C_{4}$ & & & & 1.000 & -0.409 & 0.731 \\
$C_{5}$ & & & & & & -0.100 \\
$I_{1}$ & & & & & 1.000 \\
\hline
\end{tabular}

Table 3. Pearson correlations on the economic factors and CWM performance indicators for Europe.

\begin{tabular}{|c|c|c|c|c|c|c|c|c|}
\hline & $C_{1}$ & $C_{2}$ & $C_{5}$ & $I_{1}$ & $I_{2}$ & $I_{3}$ & $I_{4}$ & $I_{5}$ \\
\hline $\begin{array}{l}C_{1} \\
C_{2} \\
C_{5} \\
I_{1} \\
I_{2} \\
I_{3} \\
I_{4} \\
I_{5}\end{array}$ & 1.000 & $\begin{array}{l}1.000 \\
1.000\end{array}$ & $\begin{array}{l}0.379 \\
0.377 \\
1.000\end{array}$ & $\begin{array}{l}0.818 \\
0.802 \\
0.773 \\
1.000\end{array}$ & $\begin{array}{l}0.842 \\
0.828 \\
0.806 \\
0.999 \\
1.000\end{array}$ & $\begin{array}{c}0.362 \\
0.349 \\
0.054 \\
-0.032 \\
-0.025 \\
1.000\end{array}$ & $\begin{array}{l}0.817 \\
0.793 \\
0.666 \\
0.957 \\
0.950 \\
0.218 \\
1.000\end{array}$ & $\begin{array}{c}-0.848 \\
-0.832 \\
-0.781 \\
-0.997 \\
-0.996 \\
-0.045 \\
-0.973 \\
1.000\end{array}$ \\
\hline
\end{tabular}

Table 4. Pearson correlations on the economic factors and CWM performance indicators for Hong Kong.

\begin{tabular}{cccccccc}
\hline & $C_{1}$ & $C_{2}$ & $C_{3}$ & $C_{5}$ & $I_{1}$ & $I_{2}$ & $I_{3}$ \\
\hline$C_{1}$ & 1.000 & 1.000 & 0.615 & -0.621 & -0.246 & -0.242 & -0.787 \\
$C_{2}$ & & 1.000 & 0.608 & -0.627 & -0.259 & -0.254 & -0.789 \\
$C_{3}$ & & & 1.000 & -0.243 & -0.272 & 0.185 & -0.056 \\
$C_{5}$ & & & & 1.000 & 0.679 & 0.688 & 0.456 \\
$I_{1}$ & & & & & 1.000 & 0.887 & 0.467 \\
$I_{2}$ & & & & & & & \\
$I_{3}$ & & & & & & \\
\hline
\end{tabular}

Table 5. Pearson correlations on the economic factors and CWM performance indicators for the United Kingdom.

\begin{tabular}{|c|c|c|c|c|c|c|c|c|}
\hline & $C_{1}$ & $C_{2}$ & $C_{3}$ & $C_{4}$ & $C_{5}$ & $I_{1}$ & $I_{4}$ & $I_{5}$ \\
\hline $\begin{array}{l}C_{1} \\
C_{2} \\
C_{3} \\
C_{4} \\
C_{5} \\
I_{1} \\
I_{4} \\
I_{5}\end{array}$ & 1.000 & $\begin{array}{l}0.995 \\
1.000\end{array}$ & $\begin{array}{l}0.392 \\
0.438 \\
1.000\end{array}$ & $\begin{array}{c}-0.193 \\
-0.181 \\
0.158 \\
1.000\end{array}$ & $\begin{array}{c}0.440 \\
0.577 \\
0.558 \\
-0.083 \\
1.000\end{array}$ & $\begin{array}{l}0.216 \\
0.330 \\
0.640 \\
0.199 \\
0.811 \\
1.000\end{array}$ & $\begin{array}{c}1.000 \\
1.000 \\
0.998 \\
0.482 \\
- \\
0.477 \\
1.000\end{array}$ & $\begin{array}{c}-1.000 \\
-1.000 \\
0.797 \\
0.887 \\
- \\
0.884 \\
0.832 \\
1.000\end{array}$ \\
\hline
\end{tabular}

It assumes the same trend for the sum of the reduced, reused, and recycled C \& D waste $\left(I_{4}\right)$ and landfill waste $\left(I_{5}\right)$ with respect to the total C \& D waste $\left(I_{1}\right)$ to the total inert C \& D waste $\left(I_{2}\right)$ and non-inert $C \& \mathrm{D}$ waste $\left(I_{3}\right)$ with respect to the total $C \& \mathrm{D}$ waste $\left(I_{1}\right)$. The total inert $C \& \mathrm{D}$ waste $\left(I_{2}\right)$ received high correlations with the total C \& D waste $\left(I_{1}\right)$ of about 0.999 and 0.887 for Europe 
and Hong Kong, respectively. However, these two economies did not receive high correlations with the non-inert $C \& D$ waste $\left(I_{3}\right)$ with the total $C$ \& D waste $\left(I_{1}\right)$ of which only -0.032 and 0.467 are received for Europe and Hong Kong, respectively. This indicates that the non-inert $C \& D$ waste is not producing consistently with the total C \& D waste.

Europe, Hong Kong, and the United Kingdom basically have high correlations with all indicators in the CWM performance $\left(I_{1}-I_{6}\right)$ except the total non-inert C \& D waste $\left(I_{3}\right)$ in Europe and Hong Kong and the reduced, reused, and recycled C \& D waste $\left(I_{4}\right)$ in the United Kingdom. As the total C \& $\mathrm{D}$ waste volume $\left(I_{1}\right)$ is the only data available for all selected countries, which is the representative indicator in the CWM performance comparisons across countries.

In the economic profiles, it is clear that the total GDP $\left(C_{1}\right)$ and GDP per capita $\left(C_{2}\right)$ are strongly correlated with at least 0.869 for different countries. Total construction output $\left(C_{3}\right)$ is only strongly correlated with the total GDP $\left(C_{1}\right)$ and GDP per capita $\left(C_{2}\right)$ of about 0.978 and 0.967 respectively in Australia while only about 0.392 and 0.438 respectively in the United Kingdom. This indicates that the United Kingdom did not receive growing construction output as the total GDP has been improving from the past years.

The negative correlations found from the construction of new buildings $\left(C_{5}\right)$ with other economic profiles indicators in Australia and Hong Kong indicate that there is a reduction of the construction of new buildings while on the other hand the total GDP, construction output, and construction productivity have improved over the past years. As there is no common parameter under the economic profiles providing consistently strong correlation to CWM among countries, the total GDP $\left(C_{1}\right)$ is thus used for comparison purposes among different countries.

\subsection{Cross-Jurisdictional Analyses of CWM Performance and Their Causal Factors}

For comparing CWM performance with respect to the economic profile among countries, ratios of the total C \& D waste volume $\left(I_{1}\right)$ per total GDP $\left(C_{1}\right) \times 1000$ are used to produce the value of $I_{6}$ : $C \& D$ waste generation per construction GDP in the unit of million tons/million US\$. The results are summarized in Tables 2-5. As also shown in Figure 2, the ratios are very similar of which Australia has a range between 28.48 and 44.04; Europe between 47.00 and 58.89; Hong Kong between 39.85 and 120.86; and the United Kingdom between 34.29 and 51.53 .

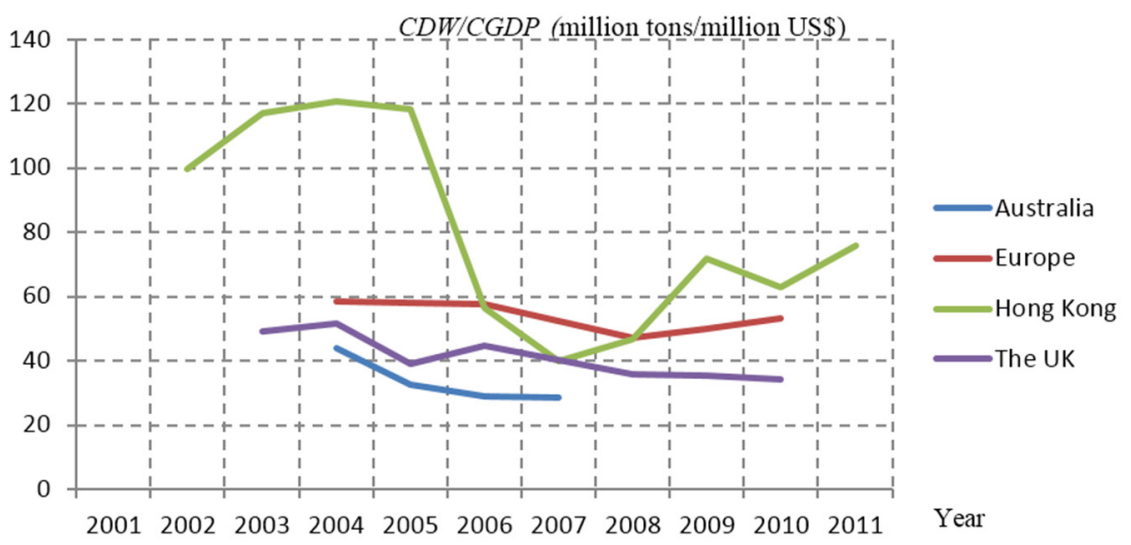

Figure 2. Trends of CDW/CGDP across Australia, Europe, Hong Kong, and the United Kingdom.

Generally speaking, most countries have a declining trend in terms of waste generation. This implies that environmental awareness has been largely improved around the world, which in turn leads to a "greener" construction sector in these countries. Except for Hong Kong, the other three economies have a relatively convergent range of waste generation in producing every million US\$ worth of work. This is evident by the gentle distribution curves in Figure 2. The temptation is to say 
that waste management technologies and practices have been stabilized after they were consistently implemented in the developed world but this needs to be further substantiated.

The radical change in Hong Kong was caused by a C \& D waste Disposal Charging Scheme enacted since 2006 (CWDCS) [59]. In line with the scheme, a construction contractor will be imposed a levy of HK $\$ 125$ for every ton of C \& D waste it disposes of at landfills; it will be levied HK $\$ 100$ per ton if the C \& D waste was accepted by off-site sorting facilities while it will be charged only HK \$27 (or US\$3.47) per ton if the waste consists entirely of inert materials accepted by public fill reception facilities. Hao, Hills [60] reported that waste has been reduced by approximately $60 \%$ in landfills, by approximately $23 \%$ in public fills, and by approximately $65 \%$ in total waste between 2005 and 2006. Lu and Tam [39] reported that the CWDCS is one of the most effective CWM policies in reducing $C \& D$ waste disposal of at landfills, and in turn, in slowing down the depletion of the limited landfills. In other economies, C \& D waste disposal charging has long been in presence based on the "polluter pays principle". In Europe, landfill tax rates vary greatly from one country to another. In the United Kingdom, for example, a landfill tax was introduced as early as in 1996, although the rate is subject to adjustment year by year; the rates for 2012 are $£ 64$ (or US\$110) per ton for active waste and $£ 2.50$ (or US\$4.29) per ton for inactive waste [61]. Austria charges $€ 9.20 / t$ (US\$12.6/t) of construction material and soil deposited in landfills. Finland charged $€ 40 / t$ (US\$54.9/t) as of 2011, with a rise to $€ 50 / \mathrm{t}$ (US\$68.7/t) planned in 2013. Meanwhile, C \& D waste landfilling is banned in the Netherlands (Cambridge Econometrics, 2013). In 2009, the Commonwealth published a report, identifying that landfill costs in Australia ranged from AU\$42 to AU \$102 (or from US\$39 to US\$95) per ton. In addition to the cost of land-filling by operators, there can be an additional charge levied by the state and territory jurisdictions.

The fluctuation in CDW/CGDP in Hong Kong between 2006 and 2011 is contributed to an inert and non-inert dichotomy adopted, whereby the inert materials, comprising mainly sand, bricks, and concrete, are deposited at public filling areas for land reclamation, while the non-inert portion, consisting of materials such as bamboo, plastics, glass, wood, paper, vegetation, and other organic materials, is disposed of at landfills as solid waste [39]. In recent years, land reclamation in Hong Kong is shrinking and the inert materials were transported to the adjacent cities for land reclamation there. Gradually, transporting the processed C \& D waste to the mainland is becoming more difficult, since China tightened regulations [62].

The indicators of CDW/CGDP in Australia, Europe, and the United Kingdom are consistently low but still with variations. In comparison, Hong Kong has a relatively high CDW/CGDP. It would be interesting to explore the reasons behind the variations of CDW/CGDP as this will help benchmark performance and identify best CWM practices. For example, it is hypothesized that types of construction projects and their associated technologies will help explain the variations. 1-2 floor houses are prevailing in Australia, EU-27 States, and the UK, while high-rise buildings are predominant in Hong Kong. Wooden structures or full steel structures are popular for homes and commercial buildings respectively in the UK, EU-27, and Australia, while concrete structures are most often adopted in Hong Kong. Waste generation should present different patterns in these economies. In addition, it is also hypothesized that different development stages will help explain the variations of CDW/CGDP. In developed economies such as the UK, EU-27 States, and Australia, new construction and renovation should be dominant waste activities. Hong Kong is well developed but it suffers from a decayed infrastructure in a very compacted area; demolition and new construction play an equally important role in contributing to waste generation. These factors should be used as control variables in examining the links between CWM performance indicators and CWM practices by putting them in different economic profiles. However, the attempt is currently hampered by a general lack of data on waste management practices in individual economy. 


\subsection{Drawbacks of the Comparison and Future Studies}

This research is yet to include benchmarking hazardous construction waste management performance across different economies, despite its urgency to devising warranted abatement actions. Many materials such as leaded paint [63,64], asbestos [65], or radioactive substances [66] were legitimately adopted in construction decades ago but they are increasingly recognized as hazards nowadays. Normally, these hazardous C \& D wastes are regulated by separate regulations, e.g., the Waste Disposal (Chemical Waste) (General) Regulation 1992 in Hong Kong. The waste is not counted as the C \& D waste in the above comparisons amongst the developed economies with a matured hazardous waste handling mechanism. However, in most developing countries, the hazardous C \& D waste is normally mixed with the ordinary C \& D waste without proper handling. CWM performance benchmarking of this kind, particularly amongst developing countries, thus should alert readers of the huge impact of the hazardous C \& D waste instead of focusing on CDW /CGDP only. Tailor-made indicators are desired for this type of benchmarking in future studies.

Regardless of the paper actually reflecting the best data currently available, the benchmarking is still suffering from erratic data availability (see the Appendix). The data are thus not allowing for more robust analyses on the causal effects between economic profiles, CWM practice and a less/more wasteful construction sector. It is recommended for future studies to continue this benchmarking and to extend it to more economies in the future when data is more accessible.

\section{Conclusions}

This paper conducted a cross-jurisdictional analysis on CWM among Australia, Europe, Hong Kong, and the United Kingdom. For this purpose, an indicator of $C \& D$ waste generation per construction GDP (CDW/CGDP) ( $\mathrm{mt} / \mathrm{mUS \$}$ ) is introduced as a universal benchmark that can be used to compare CWM practices across different jurisdictions. It is found that Australia has a range between 28.48 ( $\mathrm{t} / \mathrm{mUS} \$)$ and 44.04 (t/mUS\$); Europe between 47.00 (t/mUS\$) and 58.89 (t/mUS\$); Hong Kong between $39.85(\mathrm{t} / \mathrm{mUS} \$)$ and $120.86(\mathrm{t} / \mathrm{mUS} \$)$; and the United Kingdom between $34.29(\mathrm{t} / \mathrm{mUS} \$)$ and 51.53 (t/mUS\$) in their waste generation. Generally speaking, most countries witnessed a declining trend in terms of waste generation. The efforts to promote a "greener" construction industry around the developed world have largely paid off. Whilst acknowledging that waste generation is inherently linked to the profile and practice of an economy, in particular its construction industry, sharing knowledge in this area can help improve waste management, as evident by the relatively low and stable CDW/CGDP in these countries.

It was the ambition of the authors to include more economies such as the United States, China, and Japan to increase the generality of this cross-jurisdictional comparison but the effort is hampered by a lack of data from some countries, even in the countries that have a long history of statistics. The attempt in this paper will be gaining momentum when more and more economies start to publish their statistics on C \& D waste, which often constitutes a significant portion of the total MSW in contributing to the environment degradation. In this sense, the paper is a pioneer of encouraging sharing CWM knowledge across borders and the results should be viewed in that light.

Acknowledgments: The research was supported by the National Nature Science Foundation of China (NSFC) (project No.: 71273219) and the Hong Kong Research Grants Council (RGC) Public Policy Research (PPR) Scheme (RGC Ref. HKU7016-PPR-11). Ms. Paola Villoria Saez from Technical University of Madrid, Spain, and Mr. Hongdi Wang from The University of Hong Kong are much appreciated for their research assistance.

Author Contributions: Both authors have contributed equally to the designed research, researched and analyzed the data, and wrote up the paper. Both authors have read and approved the final manuscript.

Conflicts of Interest: Both authors have no conflict of interests to any other parties. 


\section{Appendix}

Table A1. The economic profile and CWM performance indicators in Australia.

\begin{tabular}{|c|c|c|c|c|c|c|c|c|c|c|c|}
\hline Year & 2001 & 2002 & 2003 & 2004 & 2005 & 2006 & 2007 & 2008 & 2009 & 2010 & 2011 \\
\hline$I_{1}$ & 18.60 & 19.48 & 19.58 & 20.55 & 20.00 & 20.00 & 21.22 & 19.0 & - & - & - \\
\hline$I_{2}$ & - & - & - & - & - & - & - & - & - & - & - \\
\hline$I_{3}$ & - & - & - & - & - & - & - & - & - & - & - \\
\hline$I_{4}$ & - & - & - & - & - & - & - & 10.5 & - & - & - \\
\hline$I_{5}$ & - & - & - & - & - & - & - & 8.5 & - & - & - \\
\hline$I_{6}$ & - & - & - & 44.04 & 32.71 & 28.89 & 28.48 & - & - & - & - \\
\hline$C_{1}$ & - & - & - & 466.50 & 611.50 & 692.40 & 745.00 & 850.50 & 1052.30 & 923.50 & 1138.30 \\
\hline$C_{2}$ & - & $20,100.99$ & $23,445.60$ & $30,375.83$ & $33,944.98$ & $35,986.07$ & $40,352.39$ & $48,971.68$ & $42,000.01$ & $51,085.68$ & $60,979.03$ \\
\hline$C_{3}$ & $56,010.67$ & $66,085.24$ & $72,804.76$ & 81031.81 & $95,778.76$ & $107,228.48$ & $122,639.52$ & $144,095.62$ & $152,291.05$ & $158,137.52$ & $186,506.48$ \\
\hline$C_{4}$ & $65,438.19$ & $73,418.29$ & $72,757.71$ & $70,658.67$ & $72,542.38$ & $71,354.76$ & $74,450.57$ & $74,868.95$ & & & \\
\hline$C_{5}$ & & & & $13,568.00$ & $13,747.00$ & $12,136.00$ & $12,687.00$ & $12,104.00$ & $12,176.00$ & $12,683.00$ & $12,487.00$ \\
\hline
\end{tabular}

Note: $\mathrm{I}_{1}: ; \mathrm{I}_{2}$ : Total inert construction waste volume (million tons); $\mathrm{I}_{3}$ : Total non-inert construction waste volume (million tons); $\mathrm{I}_{4}$ : Total volumes of construction waste reduced, reused and recycled (million tons); $\mathrm{I}_{5}$ : Total volume of construction waste landfilled (million tons); $\mathrm{I}_{6}$ : Construction waste generation per construction GDP (million tons/million US\$); $\mathrm{C}_{1}$ : Total GDP (billion US\$); $\mathrm{C}_{2}$ : GDP per capita (US\$); $\mathrm{C}_{3}$ : Total construction output (million US\$); $\mathrm{C}_{4}$ : Construction productivity (million US\$); and $\mathrm{C}_{5}$ : Construction of new buildings (numbers).

Table A2. The economic profile and CWM performance indicators in Europe.

\begin{tabular}{|c|c|c|c|c|c|c|c|c|c|c|c|}
\hline Year & 2001 & 2002 & 2003 & 2004 & 2005 & 2006 & 2007 & 2008 & 2009 & 2010 & 2011 \\
\hline$I_{1}$ & - & - & - & 772.32 & - & 844.31 & - & 858.42 & - & 857.16 & - \\
\hline$I_{2}$ & - & - & - & 733.36 & - & 799.11 & - & 815.50 & - & 809.52 & - \\
\hline$I_{3}$ & - & - & - & 38.96 & - & 45.20 & - & 42.92 & - & 47.64 & - \\
\hline$I_{4}$ & - & - & - & 200.20 & - & 230.22 & - & 244.45 & - & 253.60 & - \\
\hline$I_{5}$ & - & - & - & 234.78 & - & 216.10 & - & 210.29 & - & 210.60 & - \\
\hline$I_{6}$ & - & - & - & 58.59 & - & 57.47 & - & 47.00 & - & 53.00 & - \\
\hline$C_{1}$ & - & 9362.60 & $11,417.50$ & $13,181.43$ & $13,781.44$ & $14,692.49$ & $16,990.03$ & $18,263.51$ & $16,320.79$ & $16,173.41$ & $17,574.41$ \\
\hline$C_{2}$ & - & $19,261.87$ & $23,388.77$ & $26,878.28$ & $27,975.69$ & $29,699.36$ & $34,187.80$ & $36,588.34$ & $32,584.00$ & $32,198.55$ & $34,892.00$ \\
\hline$C_{3}$ & - & - & - & - & - & - & - & - & - & - & - \\
\hline$C_{4}$ & - & - & - & - & - & - & - & - & - & - & - \\
\hline$C_{5}$ & 2200.00 & $13,200.00$ & $10,800.00$ & $18,600.00$ & 400.00 & $37,400.00$ & 8600.00 & $59,800.00$ & $80,400.00$ & $33,600.00$ & 400.00 \\
\hline
\end{tabular}


Table A3. The economic profile and CWM performance indicators in Hong Kong.

\begin{tabular}{|c|c|c|c|c|c|c|c|c|c|c|c|}
\hline Year & 2001 & 2002 & 2003 & 2004 & 2005 & 2006 & 2007 & 2008 & 2009 & 2010 & 2011 \\
\hline$I_{1}$ & 14.18 & 16.57 & 18.87 & 20.44 & 21.45 & 10.91 & 8.43 & 10.23 & 15.40 & 14.40 & 18.80 \\
\hline$I_{2}$ & 11.84 & 12.84 & 16.42 & 18.03 & 19.06 & 9.40 & 7.28 & 9.10 & 14.26 & 13.10 & 17.58 \\
\hline$I_{3}$ & 2.34 & 3.72 & 2.46 & 2.41 & 2.39 & 1.51 & 1.15 & 1.13 & 1.14 & 1.31 & 1.22 \\
\hline \multicolumn{12}{|l|}{$I_{4}$} \\
\hline$I_{5}$ & - & - & - & - & - & - & - & - & - & - & - \\
\hline$I_{6}$ & - & 99.58 & 116.95 & 120.86 & 118.14 & 56.36 & 39.85 & 46.64 & 71.93 & 62.95 & 75.60 \\
\hline$C_{1}$ & - & 166.35 & 161.38 & 169.10 & 181.57 & 193.54 & 211.60 & 219.28 & 214.05 & 228.82 & 248.61 \\
\hline$C_{2}$ & - & $24,665.89$ & $23,977.02$ & $24,928.10$ & $26,649.75$ & $28,224.22$ & $30,551.61$ & $31,425.78$ & $30,561.91$ & $32,374.48$ & $35,156.39$ \\
\hline$C_{3}$ & $14,613.59$ & $13,589.74$ & $12,696.41$ & $11,945.00$ & $11,647.56$ & $11,567.95$ & $11,905.90$ & $12,769.10$ & $12,941.54$ & $14,265.90$ & $16,478.85$ \\
\hline$C_{4}$ & - & - & - & - & - & - & - & - & - & - & - \\
\hline$C_{5}$ & - & - & - & 4058.00 & 3603.00 & 1867.00 & 1526.00 & 2902.00 & 2280.00 & 1837.00 & 2352.00 \\
\hline
\end{tabular}

Table A4. The economic profile and CWM performance indicators in the United Kingdom.

\begin{tabular}{|c|c|c|c|c|c|c|c|c|c|c|c|}
\hline Year & 2001 & 2002 & 2003 & 2004 & 2005 & 2006 & 2007 & 2008 & 2009 & 2010 & 2011 \\
\hline$I_{1}$ & 88.89 & - & 90.93 & 113.20 & 89.60 & 109.55 & - & 94.54 & 76.97 & 77.38 & - \\
\hline$I_{2}$ & - & - & - & - & - & - & - & - & - & - & - \\
\hline$I_{3}$ & - & - & - & - & - & - & - & - & - & - & - \\
\hline$I_{4}$ & 43.56 & - & 45.47 & - & 46.59 & - & - & - & - & - & - \\
\hline$I_{5}$ & 23.11 & - & 29.10 & - & 27.78 & - & - & - & - & - & - \\
\hline$I_{6}$ & - & - & 49.00 & 51.53 & 39.03 & 44.66 & - & 35.69 & 35.24 & 34.29 & - \\
\hline$C_{1}$ & - & 1601.62 & 1855.67 & 2196.86 & 2295.84 & 2452.97 & 2825.53 & 2648.94 & 2183.86 & 2256.26 & 2445.41 \\
\hline$C_{2}$ & - & $26,996.97$ & $31,152.99$ & $36,695.14$ & $38,121.56$ & $40,480.96$ & $46,330.25$ & $43,146.83$ & $35,331.28$ & $36,256.01$ & $39,038.46$ \\
\hline$C_{3}$ & $114,295.59$ & $127,895.76$ & $142,724.52$ & $156,615.39$ & $163,719.18$ & $171,972.31$ & $175,591.52$ & $170,836.89$ & $147,857.10$ & $159,560.18$ & $163,545.83$ \\
\hline$C_{4}$ & $48,714.44$ & $50,012.64$ & $50,783.30$ & $50,710.01$ & $49,444.09$ & $49,145.74$ & $49,426.19$ & $49,317.10$ & $46,404.14$ & $51,948.24$ & - \\
\hline$C_{5}$ & - & - & - & $16,958.00$ & $17,465.00$ & $17,732.00$ & $18,869.00$ & $15,692.00$ & $13,218.00$ & $11,440.00$ & $11,830.00$ \\
\hline
\end{tabular}




\section{References}

1. United Nations Centre for Human Settlements. People, Settlements, Environment and Development; United Nations Centre for Human Settlements: Nairobi, Kenya, 1990.

2. United Nations Centre for Human Settlements. Development of National Capacity for Environmental Sound Construction; United Nations Centre for Human Settlements: Nairobi, Kenya, 1993.

3. Ofori, G. The environment: The fourth construction project objective? Constr. Manag. Econ. 1992, 10, 369-395. [CrossRef]

4. Worldwatch Institute. State of the World 1995; Norton: New York, NY, USA, 1995.

5. Poon, C.S.; Yu, A.T.W.; See, S.C.; Cheung, E. Minimizing demolition wastes in Hong Kong public housing projects. Constr. Manag. Econ. 2004, 22, 799-805. [CrossRef]

6. Brown, L.R.; Flavin, C.; Kane, H. Vital Signs 1996: The Trends That Are Shaping Our Future; Norton Co. and Worldwatch Institute: New York, NY, USA, 1996.

7. Lenssen, N.; Roodman, D.M. Making Better Buildings in State of the World 1995; Worldwatch Institute: New York, NY, USA, 1995; pp. 95-112.

8. Bossink, B.; Brouwers, H. Construction waste: Quantification and source evaluation. J. Constr. Eng. Manag. 1996, 122, 55-60. [CrossRef]

9. Tam, W.Y.V. On the effectiveness in implementing a waste-management-plan method in construction. Waste Manag. 2008, 28, 1072-1080. [CrossRef] [PubMed]

10. Lu, W.; Yuan, H.P. A framework of understanding waste management studies in construction. Waste Manag. 2011, 31, 1252-1260. [CrossRef] [PubMed]

11. Australian Government. Construction and Demolition Waste Guide-Recycling and Re-use Across the Supply Chain. 2015. Available online: https://www.environment.gov.au/system/files/resources/ b0ac5ce4-4253-4d2b-b001-0becf84b52b8/files/case-studies.pdf (accessed on 19 February 2016).

12. Boiral, O.; Henri, J.F. Modelling the impact of ISO 14001 on environmental performance: A comparative approach. J. Environ. Manag. 2012, 99, 84-97. [CrossRef] [PubMed]

13. Coelho, A.; de Brito, J. Influence of construction and demolition waste management on the environmental impact of buildings. Waste Manag. 2012, 32, 532-541. [CrossRef] [PubMed]

14. Yuan, H.P.; Chini, A.R.; Shen, L.Y. A dynamic model for assessing the effects of management strategies on the reduction of construction and demolition waste. Waste Manag. 2012, 32, 521-531. [CrossRef] [PubMed]

15. Comoglio, C.; Botta, S. The use of indicators and the role of environmental management systems for environmental performances improvement: A survey on ISO 14001 certified companies in the automotive sector. J. Clean. Prod. 2012, 20, 92-102. [CrossRef]

16. Environmental Protection Department. Monitoring of Solid Waste in Hong Kong 2012. 2014. Available online: https://www.wastereduction.gov.hk/en/assistancewizard/waste_red_sat.htm (accessed on 19 February 2016).

17. Ramzy, A. China's Mountains of Construction Rubble; New York Times: New York, NY, USA, 2013.

18. Qiu, B.X. Six areas for China's building energy saving and my prospects. In Proceedings of the Keynote Speech on The 6th International Conference of Green Buildings and Energy-Efficiency, Beijing, China, 29-31 March 2010.

19. Hyder Consulting. Construction and Demolition Waste Status Report-Management of Construction and Demolition Waste in Australia; Hyder Consulting: Melbourne, Australia, 2011.

20. Eurostat. Breakdown of Total Waste Generation by Waste Category Coverage of Generation Indicator EU 27 2010. Eurostat: Luxembourg, 2014. Available online: http://appsso.eurostat.ec.europa.eu/nui/show.do (accessed on 19 February 2016).

21. Department for Environment Food \& Rural Affairs. Construction and Demolition Waste; Department for Environment Food \& Rural Affairs: London, UK, 2014.

22. United States Environmental Protection Agency. Construction and Demolition Waste; United States Enviornmental Protection Agency: New York, NY, USA, 2009.

23. McCabe, S. Benchmarking in Construction; John Wiley and Sons: Hoboken, NJ, USA, 2008.

24. Ioppolo, G.; Heijungs, R.; Cucurachi, S.; Salomone, R.; Kleijn, R. Urban metabolism: Many open questions for future answers. In Pathways to Environmental Sustainability: Methodologies and Experiences; Salomone, R., Saija, G., Eds.; Springer International Publishing: Cham, Switzerland, 2014; pp. 23-32. 
25. Cseh-Szombathy, L. Sociology of Marital Conflicts; Budapest Gondolat Kiado: Budapest, Hungary, 1985.

26. Hantrais, L.; Mangen, S. Cross-National Research Methods in the Social Sciences; Printer: London, UK; New York, NY, USA, 1996.

27. Kofoworola, O.F.; Gheewala, S.H. Estimation of construction waste generation and management in Thailand. Waste Manag. 2009, 29, 731-738. [CrossRef] [PubMed]

28. Roche, T.D.; Hegarty, S. Best Practice Guidelines on the Preparation of Waste Management Plans for Construction and Demolition Projects; Department of the Environment, Community and Local Government: Dublin, Ireland, 2006.

29. Serpell, A.; Alarcon, L.F. Construction process improvement methodology for construction projects. Int. J. Project Manag. 1998, 16, 215-221. [CrossRef]

30. Horman, M.J.; Kenley, R. Quantifying levels of wasted time in construction with meta-analysis. J. Constr. Eng. Manag. 2005, 131, 52-61. [CrossRef]

31. Womack, J.P.; Jones, D.T. Lean Thinking: Banish Waste and Create Wealth in Your Corporation; Free Press: New York, NY, USA, 2003.

32. Pinto, T.P. Material Waste in Traditional Construction Processes; Research Rep.; Federal University of São Carlos: São Carlos, Brazil, 1989. (In Portuguese)

33. Formoso, C.T.; Soibelman, L.; de Cesare, C.; Isatto, E.L. Material waste in building industry: Main causes and prevention. J. Constr. Eng. Manag. 2002, 128, 316-325. [CrossRef]

34. Koskela, L. An Exploration towards a Production Theory and Its Application to Construction; VTT Technical Research Centre of Finland: Espoo, Finland, 2000.

35. Business Dictionary. Inert Waste and Non-Inert Waste; Business Dictionary: New York, NY, USA, 2014.

36. Treloar, G.J.; Gupta, H.; Love, P.E.D.; Nguyen, B. An analysis of factors influencing waste minimization and use of recycled materials for the construction of residential buildings. Manag. Environ. Qual. Int. J. 2003, 14, 134-145. [CrossRef]

37. Tam, V.W.Y. The effectiveness of the green building evaluation and labelling system. Archit. Sci. Rev. 2007, 50, 323-330. [CrossRef]

38. Katz, A.; Baum, H. A novel methodology to estimate the evolution of construction waste in construction sites. Waste Manag. 2011, 31, 353-358. [CrossRef] [PubMed]

39. Lu, W.S.; Tam, W.Y.V. Construction waste management policies and their effectiveness in Hong Kong: A longitudinal review. Renew. Sustain. Energy Rev. 2013, 23, 214-223. [CrossRef]

40. Peng, C.L.; Scorpio, D.E.; Kibert, C.J. Strategies for successful construction and demolition waste recycling operations. J. Constr. Manag. Econ. 1997, 15, 49-58. [CrossRef]

41. Poon, C.S. Reducing construction waste. Waste Manag. 2007, 27, 1715-1716. [CrossRef] [PubMed]

42. Esin, T.; Cosgun, N. A study conducted to reduce construction waste generation in Turkey. Build. Environ. 2007, 42, 1667-1674. [CrossRef]

43. Seydel, A.; Wilson, O.D.; Skitmore, R.M. Financial evaluation of waste management methods: A case study. J. Constr. Res. 2002, 3, 167-179. [CrossRef]

44. Begum, R.A.; Siwar, C.; Pereira, J.J.; Jaafar, A.H. Implementation of waste management and minimization in the construction industry of Malaysia. Resour. Conserv. Recycl. 2007, 51, 190-202. [CrossRef]

45. Ling, Y.Y.; Leo, K.C. Reusing timber formwork: Importance of workmen's efficiency and attitude. Build. Environ. 2000, 35, 135-143. [CrossRef]

46. Duran, X.; Lenihan, H.; O'Regan, B. A model for assessing the economic viability of construction and demolition waste recycling-The case of Ireland. Resour. Conserv. Recycl. 2006, 46, 302-320. [CrossRef]

47. Building Research Establishment Environmental Assessment Method. 2008. Available online: http://www. bre.co.uk (accessed on 8 July 2008).

48. Canadian Standards Association. Green Globes System. 2012. Available online: http://www.greenglobes. com/about.asp (accessed on 14 July 2012).

49. HK-BEAM Society. HK-BEAM. 2007. Available online: https://www.hkgbc.org.hk/eng/BEAMPlus_ NBEB.aspx (accessed on 7 June 2007).

50. U.S. Green Building Council. Leadership in Energy and Environmental Design. 2008. Available online: http:/ / www.usgbc.org (accessed on 18 July 2008).

51. Green Building Council of Australia. Green Star Environmental Assessment System; Green Building Council of Australia: Sydney, Australia, 2012; Volume 2012. 
52. Building and Construction Authority-Singapore Government. Green mark assessment system. 2012. Available online: http:/ /bca.gov.sg/GreenMark/green_mark_criteria.html (accessed on 14 July 2012).

53. Cole, R.J.; Larsson, N. Green Building Challenge-GBTool User Manual. 2002. Available online: http://www.iisbe.org/down/gbc2005/GBC2k2/GBC2k2_Manual_A4.pdf (accessed on 14 July 2012).

54. Bergsdal, H.; Bohne, R.A.; Brattebo, H. Projection of construction and demolition waste in Norway. J. Ind. Ecol. 2007, 11, 27-39. [CrossRef]

55. Ding, T.; Xiao, J. Estimating of building-related construction and demolition waste in Shanghai. Waste Manag. 2014, 34, 2327-2334. [CrossRef] [PubMed]

56. Goodman, L.A. Snowball sampling. Ann. Mathe. Stat. 1961, 32, 148-170. [CrossRef]

57. Stemler, S. An overview of content analysis. Practical Assess. Res. Eval. 2001, 7. Available online: http:/ / PAREonline.net/getvn.asp?v=7\&n=17 (accessed on 4 July 2013).

58. Pearson, K. Notes on regression and inheritance in the case of two parents. Proc. R. Soc. Lond. 1895, 58, 240-242. [CrossRef]

59. Hong Kong Government—Environmental Protection Department. Environmental Report 2006; Environmental Protection Department, Hong Kong Government: Admiralty, Hong Kong, China, 2006.

60. Hao, J.L.; Hills, M.J.; Tam, V.W.Y. The effectiveness of Hong Kong's Construction Waste Disposal Charging Scheme. Waste Manag. Res. 2008, 26, 553-558. [CrossRef] [PubMed]

61. United Kingdom Finance Act. United Kingdom Finance Act; United Kingdom Parliament: London, UK, 2012.

62. Wong, W. Government Denies Dumping of Imported Waste; RTHK English News, Hong Kong Special Administrative Region: Kowloon, Hong Kong, China, 2013.

63. Nevin, R.; Jacob, D.E.; Berg, M.; Cohen, J. Monetary benefits of preventing childhood level poisoning with lead-safe window replacement. Environ. Res. 2008, 106, 410-419. [CrossRef] [PubMed]

64. Dixon, S.L.; Jacobs, D.E.; Wilson, J.W.; Akoto, J.Y.; Nevin, R.; Scott, C.C. Window replacement and residential lead paint hazard control 12 years later. Environ. Res. 2012, 113, 14-20. [CrossRef] [PubMed]

65. NSW Government and WorkCover NSW. Management of Asbestos in Recycled Construction and Demolition Waste: Guide; NSW Government and WorkCover NSW: Sydney, Australia, 2010; pp. 1-20.

66. Berner, U.R. Evolution of pore water chemistry during degradation of cement in a radioactive waste repository environment. Waste Manag. 1992, 12, 201-219. [CrossRef]

(C) 2016 by the authors; licensee MDPI, Basel, Switzerland. This article is an open access article distributed under the terms and conditions of the Creative Commons by Attribution (CC-BY) license (http://creativecommons.org/licenses/by/4.0/). 